\title{
BOURDIEU I DUCHY
}

\section{PIOTR KULAS,}

\section{ROZMOWY O INTELIGENCJI}

Witold Zakrzewski

Uniwersytet Warszawski

Niedawno Wydawnictwo Scholar opublikowało tom rozmów warszawskiego socjologa Piotra Kulasa z jedenastoma cenionymi polskimi badaczami. W większości, co nie jest bez znaczenia, socjologami (choć znajdziemy wśród rozmówców Kulasa także filozofów, polonistów czy historyków). Powstała w ten sposób książka to jedna z tych nielicznych pozycji, które przedstawiając czytelnikowi pełną paletę możliwych interpretacji, pozwalają mu samodzielnie zastanawiać się dalej. Trwająca od XIX w. dyskusja o statusie ontologicznym i przyszłym życiu polskiej inteligencji toczyła się w tych samych koleinach aż do początku lat 90 . XX w., gdy te utarte tory dyskusji pozornie zniknęły. Padające w nowej rzeczywistości argumenty wcale jednak nie różnią się tak zasadniczo od tych wykorzystywanych 100 lat temu.

Piotr Kulas skonstruował swoją książkę bardzo przebiegle. Mentorom różnych pokoleń inteligencji o odmiennych zupełnie barwach politycznych (Andrzej Mencwel, Paweł Śpiewak, Dariusz Gawin) towarzyszą zajmujący się w swoich badaniach bezpośrednio kategorią inteligencji badacze tacy jak Henryk Domański czy Tomasz Zarycki. Wszyscy, nawet jeżeli rytualnie odżegnują się od etosu inteligenckiego (jak Agata Bielik-Robson), w jakimś stopniu tonem intymnego zwierzenia bądź zimnej socjologicznej analizy mówią o sobie samych. Kulas nie słucha potulnie swoich utytułowanych rozmówców i zadaje krótkie, celne pytania, rozsadzające retoryczną spójność ich wywodów. Poprzedzający właściwe wywiady wstęp doskonale rozrysowuje mape konceptualizacji pojęcia inteligencji pojawiających się w kolejnych wywiadach. Czytelnik zostaje więc w jakiś sposób uodpornio- 
ny na zetknięcie się z kolejnymi znanymi mu zazwyczaj wcześniej poglądami, ale tym razem przedstawionymi w sposób bardziej dojmujący i odwołujący się do osobistego doświadczenia.

Rozmówcy Kulasa nie zaskakują czytelnika obeznanego ze współczesnymi sporami wokół natury i istnienia polskiej inteligencji. Śpiewak, Gawin czy Mencwel z zupełnie różnych pozycji, ale w zasadzie jednomyślnie lamentują nad powolnym schyłkiem tej formacji społecznej. Domański oraz Bokszański chłodno i z będącej częstą chorobą zawodową socjologów pozycji bezsilnego obserwatora kreślą wizję rozkładu inteligencji oraz tryumfu nowej klasy średniej. Zarycki i Bielik-Robson w ciekawy sposób starają się pokazać zadziwiającą żywotność i siłę zamykającej się w ekskluzywnych, choć nie zawsze bardzo zamożnych, gettach starej społecznej elity. Formuła wywiadu pozwala jednak głębiej zrozumieć metodologiczne i biograficzne motywacje stojące za przyjęciem takiej, a nie innej optyki patrzenia na fenomen inteligencji. Kulas znakomicie więc wykonał zadanie, jakie postawił sobie we wstępie: opublikowane rozmowy będą oczywiście świetnym materiałem do badań jakościowych i dostarcza piszącym o polskiej inteligencji (bądź po prostu zastanawiających się nad nią) inspiracji. Z różnych, cząstkowo prawdziwych perspektyw wyłowić można składające się na pewną całość elementy - inteligencja i trwa, i rozpada się, zamyka się w gettach i prężnie działa w organizacjach pozarządowych, trwa przy dawnym etosie i wypiera się go, pielęgnuje nonkonformizm i zarazem traktuje właściwy sobie kod kulturowy jako formę salonowego poloru.

Zebranie rozproszonej w umysłach rozmówców Kulasa wiedzy nie daje jednak żadnej odpowiedzi na pytanie o przyszłość polskiej struktury społecznej. Nawet ludzie tak przywiązani do inteligenckiego etosu jak Dariusz Gawin mówią jedynie o powolnym sadzeniu, pielęgnowaniu i owocowaniu drzew. Apologeci inteligencji posługują się raczej retoryką przetrwania i wyraźnie brakuje im imperialnych zapędów. Być może właśnie dlatego przez 27 lat od upadku komunizmu nie udało się nikomu sformułować jakichkolwiek konkluzywnych odpowiedzi na nurtujące polskich inteligentów i postinteligentów pytania.

Praktycznie wszyscy rozmówcy Kulasa albo odwołują się do przeszłości warstwy inteligenckiej i czerpią z niej żywotne soki, albo z obojętnością lub nawet pewnym rodzajem satysfakcji obserwuja ,naturalny” $i$,nieunikniony" proces społeczny prowadzący do jej zaniku. Niektórzy, jak Agata Bielik-Robson czy Tomasz Zarycki, dzielą się kilkoma błyskotliwymi spostrzeżeniami uwypuklającymi paradoks zmierzchającej i zarazem dominującej wciąż klasy społecznej. 
W wypowiedziach wszystkich zebranych przez Kulasa wybitnych badaczy uderza pewna mieszanka poczucia własnej wyjątkowości i defetyzmu. Ten dziwny stan ducha opiera się na dwóch filarach. Pierwszy z nich to przekonanie o niepowtarzalności wschodnioeuropejskiego doświadczenia inteligenckiego zbudowanego wokół odrębnej od zachodniej, głębszej duchowości. Drugi zaś to specyficznie przeżywane poczucie wyższości nad jakoby całkowicie materialistyczną rzeczywistością społeczną Zachodu. To tu, nad Wisła, garstka dawnych inteligentów kultywuje jeszcze tradycje starego świata intelektualnych debat i nocnych kuchennych rozmów. Nawet przeprowadzana permanentnie od 1999 r. reforma edukacji jawi się jako nieuchronne dostosowywanie szkół do nowej, niezrozumiałej w starym paradygmacie oświatowym, rzeczywistości.

Jeśli jednak wyzbędziemy się przeświadczenia o zupełnej wyjątkowości środkowoeuropejskiego ducha i konieczności jak najszybszego wyzbycia się naznaczających ją anomalii lub pielęgnowania tych odrębności, to znajdziemy się w zupełnie innej sytuacji intelektualnej. Odpowiedzi na pytania o rolę i przyszłość polskiej inteligencji staną się znacznie mniej rozmyte. Z jakichś względów nawet ci z rozmówców Kulasa, którzy sięgaja po narzędzia metodologiczne wypracowane przez socjologów przyglądających się strukturze własnych zachodnioeuropejskich społeczeństw (jak choćby zerkający ku Bourdieu Zarycki i Bokszański), koncentrują się wyłącznie na różnicach między jakoby zupełnie niekompatybilnymi strukturami społecznymi Francji, Niemiec czy Stanów Zjednoczonych w stosunku do Polski, Rosji czy Litwy. Ignoruja zaś mniej oczywiste, ale narzucające się podobieństwa.

Wydaje się oczywiste, że podstawową differentia specifica między Zachodem a Wschodem Europy jest natura dokonujących się w obydwu częściach kontynentu zmian społecznych. Przemiany po zachodniej stronie Łaby, ewolucyjne i konserwujące - pod płaszczykiem znacznie większego niż w Europie Wschodniej liberalizmu obyczajowego i nasycenia dyskursu publicznego hasłami równościowymi - dawne stosunki społeczne, zestawić można łatwo z dramatycznym i radykalnym zerwaniem ciagłości, jakiego doświadczono po drugiej stronie rzeki. Inteligencja na pierwszy rzut oka rzeczywiście nie wpisuje się w funkcjonalną $\mathrm{i}$ w miarę prostą hierarchizację opartą na klasach społecznych, odwołując się raczej do porządku poststanowego.

Jednakże jeśli porównamy polską inteligencję z brytyjską, francuska, niemiecka czy amerykańską klasa wyższą i wyższą klasa średnią, to dostrzeżemy wyraziste podobieństwo pewnego rodzaju dystynkcji kulturo- 
wej. Po drugiej stronie Laby wciąż istnieją licea klasyczne, egzaminy z wiedzy ogólnej (słynna francuska culture generale), elitarne uczelnie, merytokratyczne mechanizmy rekrutacji do służby publicznej i kulturalne snobizmy, nakazujące czytać książki, chodzić do teatru i słuchać muzyki klasycznej. Kapitał kulturowy jest swego rodzaju dekoracja, pozwalająca klasom dominującym ekonomicznie, relacyjnie i politycznie odróżnić się od reszty społeczeństwa. Nawykom tym towarzyszy nierzadko dyskurs odwołujący się do cnót obywatelskich i poczucia szczególnej odpowiedzialności za wspólnotę polityczną. Współczesna polska inteligencja nabrała dzisiejszych kształtów w zupełnie odmiennej sytuacji - z Polską Ludową trudno było się całkowicie utożsamić, a porządek społeczny państw komunistycznych opierał się na całkowitym rozdzieleniu Paretowskich hierarchii społecznych - elity władzy, pieniądza i kultury pokrywały się w stosunkowo niewielkim stopniu. Zarabiającym często mniej niż robotnicy inteligentom pozostał tylko jeden bezpieczny i niewymagający specjalnych starań wyróżnik tożsamościowy - znajdujący się w ich władaniu kapitał kulturowy i symboliczny.

O ile więc elity społeczne Europy Zachodniej skupiają w swoich rękach różne rodzaje kapitałów, o tyle rozdzielenie elit różnych typów w Polsce czy Rosji utrzymało się także po zmianie ustroju. Stara inteligencja przywiązana do swojej tradycji ze zdziwieniem zaczęła zauważać, że istniejące w niej hierarchie przestają być atrakcyjne dla głodnych ekonomicznego awansu ludzi. Obserwując z niesmakiem i postępującą rezygnacją nowe mechanizmy społeczne, łatwo uwierzyła w nieuchronność własnej zagłady. Tymczasem powiązanie kapitału ekonomicznego z kulturowym to efekt działania znanych przecież doskonale w polskich środowiskach akademickich Bourdiańskich mechanizmów reprodukcji społecznej. Społeczeństwa zachodnioeuropejskie i północnoamerykańskie mają oczywiście w swojej strukturze grupę ludzi dobrze wykształconych, ale niekoniecznie bardzo zamożnych. Jednakże trudno realnie awansować do klasy wyższej czy wyższej klasy średniej bez wykazania się pewną dystynkcją i snobizmami kulturowymi. Tymi samymi, które tak mocno naznaczają styl życia polskiej inteligencji. Jednocześnie przedstawiciele tej ostatniej nierzadko funkcjonują w dwóch, niewykluczających się porządkach społecznych. Z ekonomiczno-funkcjonalnego punktu widzenia należą do klasy średniej, wyższej klasy średniej czy też klasy wyższej. Ich sposób uczestnictwa w kulturze, autoidentyfikacja i posiadany kapitał symboliczny nakazuje im jednak nie wyzbywać się nabytej lub odziedziczonej tożsamości inteligenckiej. Tego rodzaju ekonomiczno-kulturowe kryteria przynależności do warstw spo- 
łecznych zastosowano zresztą choćby w głośnym badaniu Great British Class Survey (GBCS) z 2013 r., gdzie licząca 7\% społeczeństwa „elita” została wyodrębniona poprzez skrzyżowanie założonych przez badaczy minimalnych parametrów z obydwu tych hierarchii społecznych.

Warto zwrócić uwagę, że ci z rozmówców Kulasa, którzy wydają się przywiązani do etosu inteligenckiego, mówią o nim, posługując się wyłącznie kategoriami powolnej pracy organicznej, ożywczych seminariów czy bezinteresownego zaangażowania w działalność pozarządowa. Nawet ci diagnozujący wady nowej klasy średniej nie doszli do wniosku, że lepienie nowych elit dokonać się może tylko za sprawą zaplanowanej precyzyjnie i z pełna premedytacja reprodukcji. Wysokie standardy edukacyjne, prestiżowość humanistycznych elementów wykształcenia i kulturalne snobizmy mogą stać się dodatkowymi prócz ekonomicznych kryteriami rekrutacyjnymi do bardziej przypominającej swoje zachodnioeuropejskie odpowiedniczki klasy średniej. Wymagałoby to jednak ze strony inteligencji w pełni świadomego wykorzystania inżynierii społecznej, co kłóci się z egalitaryzmem wyznawanym przynajmniej deklaratywnie przez spora jej część.

Tak naprawdę więc to nie istnienie inteligencji jest wschodnioeuropejską anomalią, lecz bardzo umiarkowane zainteresowanie elit ekonomicznych kapitałem kulturowym i wstręt warstwy najbardziej zaangażowanych twórców i konsumentów kultury do definiowania pozycji społecznej przez pryzmat zamożności. Zrodzenie się w Polsce „,normalnych” elit o zachodnioeuropejskiej konsystencji wymagałoby uznania przez obydwie te grupy znaczenia pielęgnowanych przez siebie nawzajem wartości. Co ciekawe, indagowani przez Kulasa inteligenci albo chca bronić styl życia i pewien etos inteligencji przed zagłada, albo przyglądają się bez emocji jej powolnej anihilacji. Żaden $z$ nich nie zdecydował się na sformułowanie programu rekonstrukcji inteligencji jako elity społecznej, tak jakby przeszczepienie do Polski obłożonych anatemą przez Bourdieu, ale wciąż funkcjonujących w najlepsze, praktyk dominacji symbolicznej i kulturowej było czymś zasadniczo wstydliwym i niemożliwym.

Jeśli więc coś po lekturze książki Kulasa szczególnie mnie zdumiewa, to radykalna niezdolność jego rozmówców do zastosowania w polskim kontekście mechanizmów społecznych funkcjonujących wciąż w Stanach Zjednoczonych i Europie Zachodniej. Nie twierdzę oczywiście, że brytyjska, niemiecka czy włoska wyższa klasa średnia składa się wyłącznie z subtelnych czytelników poezji i wyznawców republikańskiego lub konstytucyjnego ideału. Nie odmawiam też wielu przedstawicielom nowej klasy średniej zainteresowań intelektualnych czy artystycznych. Jednak to przed- 
stawiciele zamożnej, czytającej i przywiązanej do francuskiej wyjątkowości burżuazji bardziej przypominają przedwojenna polską inteligencję niż jej współcześni następcy.

Zamiarem Piotra Kulasa było jednak wyłącznie stawianie pytań i dostarczenie czytelnikom zapisu często bardzo osobistych zmagań polskich akademików z własną inteligenckością. Wszyscy oni mówią i myślą o inteligencji jako o pewnej rzeczywistości duchowej - jej trwałości i rozkładzie. Solidarnie stronią od próby nakreślenia opartego na teoriach Pareto i Bourdieu, zakorzenionego zarazem w inteligenckiej tradycji, nowego modelu polskiej elity społecznej. Biernie obserwują lub zmagają się z rzeczywistościa w mikroskali. Polska inteligencja od 70 lat pozostaje zauroczona i sparaliżowana duchem dziejów.

Bibliografia:

/// Kulas P. 2016. Rozmony o inteligencii, Wydawnictwo Naukowe Scholar. 